\title{
Herbicide Nomenclature and Related Terminology
}

\section{C.J. SCIF RES}

"A certain degree of standardization (of terminology) is necessary to minimize misunderstanding and to facilitate communication" (Range Term Glossary Committee, 1974). ${ }^{1}$ Although the Society for Range Management is not concerned with assignment of common names to pesticides, an increasing number of papers dealing with various aspects of herbicide use for range improvement are being published by the Journal of Range Management. In these papers, trade and common names are often mixed, tending to confuse readers without a background in the properties and uses of herbicides. Such mixing of herbicide

Author is associate professor, Department of Range Science, Texas A\&M University, College Station $\mathbf{7 7 8 4 3 .}$

Approved by the director, Texas Agricultural Experiment Station, as TA-12218.

Manuscript received

${ }^{1}$ Range Term Glossary Committee, M. M. Kothmann (Chairman). 1974. A glossary of terms used in range management. 2nd Ed., Society for Range Management, Denver, Colo. 36 p. names (trademark, common, and chemical) should neither be considered by authors nor tolerated by the Journal except in cases where no common name has been assigned.

Clear understanding of the naming system for herbicides will help prevent confusion for authors and audience. All herbicides have three names or designations:

1. Common name. This is a short name to facilitate referencing of herbicidal compounds (Table 1). Common names of herbicides are assigned by the Weed Science Society of America (WSSA) nomenclature committee.

2. Chemical name. This is the actual chemical designation of the herbicidal. compound. Since many herbicides are rather sophisticated chemicals, chemical names are usually too cumbersome for routine use.

3. Trademark (trade name). The name under which the herbicide, as a commercial product, is advertised and sold. Trade names are much like colloquial names of plants in that they vary from company to company for the same basic herbicide (Table 1). In technical communications among scientists, use of trade names should 
be avoided since their use can be construed to be a proprietary endorsement. When trade names must be used

for clarity, a disclaimer statement should be employed unless, of course, the author is an employee of the

Table 1. Common names, chemical designations, and examples of trademark names of herbicides used for range improvement or which are showing promise in research. ${ }^{a}$

\begin{tabular}{ll} 
Common name & Chemical name \\
\hline Amitrole & 1. 3-amino-s-triazole \\
& 2. 3-amino-1,2,4-triazole
\end{tabular}

$\begin{array}{ll}\text { AMS } & \text { ammonium sulfamate } \\ \text { Atrazine } & \text { 2-chloro-4-(ethylamino)- } \\ & \text { 6-(isopropylamino)-s- } \\ & \text { triazine }\end{array}$

2,4-D (2,4-dichlorophenoxy) acetic acid

Dalapon 2,2-dichloropropionic acid

Dicamba 3,6-dichloro-o-anisic acid

Dichloroprop 2-(2,4-dichlorophenoxy) propionic acid

Hexaflurate $^{c}$ potassium hexafluoroarsenate

MCPA

1. [(4-chloro-o-tolyl) oxy] acetic acid

2. (2-methyl-4 chiorophenoxyacetic)

Monuron 1. 3-(p-chloropheny1)1,1-dimethylurea

2. (N'-(4-chlorophenyl)$N, N$-dimethylurea)

Paraquat 1,1'-dimethyl-4,4'-bipyridinium Ortho paraquat; Gramoxone' ion [as dichloride salts]

Picloram 4-amino-3,5,6-trichloropicolinic acid

$\begin{array}{ll}\text { Silvex } & \begin{array}{l}2-(2,4,5-\text { trichlorophenoxy }) \\ \text { propionic acid }\end{array} \\ 2,4,5-\mathrm{T} & \begin{array}{l}\text { (2,4,5-trichlorophenoxy) } \\ \text { acetic acid }\end{array}\end{array}$

Tebuthiuron ${ }^{\mathrm{c}} \quad N$-[5-(1,1-dimethylethyl)1,3,4-thiad iazol-2-yl]$N, N$ '-dimethylurea
Tordon 10K (potassium salt);

Tordon 212 (mixture with 2,4-D);

Tordon 225 (mixture with 2,4,5-T);

Tordon 101 (mixture with 2,4-D);

Tordon 155 (mixture with 2,4,5-T as esters).

Kuron; Weedone 2,4,5-TP; Silvex

Weedar 2,4,5-T; Weedone 2,4,5-T; Amine 4T; Lo-Vol 4T; Veon 2,4,5; Esteron 2,4,5; Brush-Rhap A-4T; Brush Rhap LV-OXY $-4 \mathrm{~T}$; and others.

EL-103, Spike.
Telvar manufacturer. In that case, the Journal should insert a standard disclaimer (see footnote, Table 1).

In written scientific communications, it is proper to mention the common name of the herbicide followed by the chemical designation in parenthesis at first mention. However, for ease of presentation, it is suggested that only common names be used in highlights with chemical name referenced at first mention of common name of the herbicide in the body of the paper, for example; "...2,4-D ((2,4-dichlorophenoxy) acetic acid) . . ." Thereafter, only the common name is required for adequate reference. In popular articles, use of only the common name will probably suffice for herbicide identification. Other herbicides assigned common names by WSSA are listed with appropriate chemical designation on the back cover of each issue of Weed Science.

The same approach should be adopted for referencing herbicide additives such as surfactants and emulsifiers. The formulation of herbicide used should be noted in the materials and methods section of all technical papers, since vital processes such as foliar absorption, tendency to volatilize, and proper carrier for application are strongly affected by formulation. Use of proper nomenclature will not only facilitate communication but will project a more professional image for our Society and its membership.

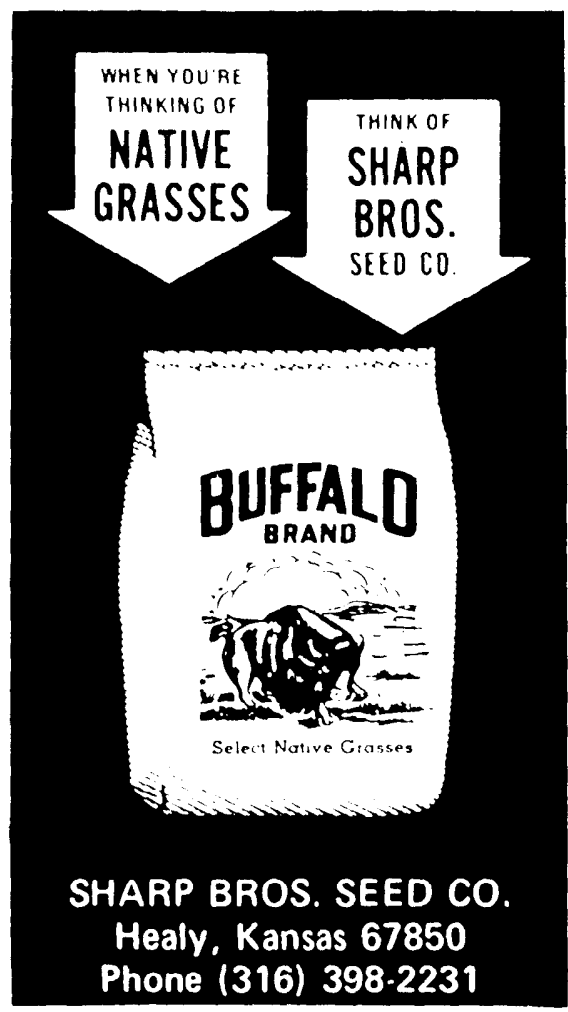

\footnotetext{
a Source: WSSA Herbicide Handbook Committee. 1974. Herbicide Handbook of the Weed Science Society of America, Third Ed. 430 p. (May be purchased from Weed Sci. Soc. Amer., 425 Illino is Bldg., 113 N. Neil St., Champaign, Ill. 61820.)

b Mention of a trademark name or a proprietary product does not constitute a guarantee or warranty of the product by the Texas Agricultural Experiment Station and does not imply its approval to the exclusion of other products that may also be suitable.

cExperimental only, not registered by Environmental Protection Agency for use on rangeland.
} 